\title{
Faith, Love, and Literacy Practices: The teaching and Learning of Qur'an and Arabic Language of Multicultural Muslims in a Single Sex Class
}

\author{
${ }^{* 1}$ Irfan Rifai, ${ }^{2}$ Fadillah Sandy \\ ${ }^{* 1}$ Bina Nusantara University, Jakarta, Indonesia, Email: irifai@binus.edu \\ ${ }^{2}$ Universitas Muhammadiyah Magelang, Central Java, Indonesia. E-mail: fadillah.sandy@ummgl.ac.id
}

Submitted: 20/09/2019

Revised: $21 / 10 / 2019$

Accepted: 21/11/2019

How to cite this article: Rifai, I., \& Sandy, F. (2019). Faith, love, and literacy practices: The teaching and learning of Qur'an and Arabic language of multicultural Muslims in a single sex class. IJELR: International Journal of Education, Language, and Religion, 1(1), 32-42. http://doi.org/10.35308/ijelr.v1i1.1769

\begin{abstract}
This article reports the literacy teaching and learning of a boys-only weekend class in a mosque of a midwestern city, United States. As part of the Muslim's community who regularly attended the weekend class that studied Qur'an and Arabic, I interviewed the participants (teacher, principal, students, and parents), observed their class interactions, took notes during and after the interactions, and gathered some artifacts that portrayed the interactions and the teaching and learning processes. Coming from various cultural background, the students and teacher demonstrated shared motivation, yet divergent interpretations on the objective and the teaching learning interactions. Taking the perspectives of ethnography of communication (Hymes, 1964; Cameron, 2001), I found that the literacy practices in this community was motivated by the love and piety of God, strong ties to their cultural background, and the perpetuation of both faith and cultural identity.
\end{abstract}

\section{Keywords}

Multiculturalism; Arabic literacy; Qur'an; single-sex class

\section{Introduction}

The negative talks, the accusation, and the prejudice explicitly stated by Donald Trump during the 2016's US presidential campaign (the time that the study was conducted in United States) on mosque portrayed the limited knowledge that the western world has on mosque and Muslims' activities happening there. Since the time of Prophet Muhammad, mosque has been used as a primary place for mainly praying, sermons, and knowledge that was transferred mainly by means of orality. Mosque in the modern world, has transformed not only as a place for acts of piety and God worshipping, but also as a space for community's gathering, cultural interactions, and the teaching of reading and writing (literacy) of Arabic language.

Literacy is not a strange word in the Muslim's world. The first word of Qur'an was iqra, meaning read or recite, which was whispered by angel Gabriel who ordered the illiterate Muham mad to learn to read. Muhammad's illiteracy represented the illiteracy level that was high during the period of time that was called Jahilliyah - "the period of ignorance," i.e. the period of time when the people were ignoring the teaching of Islam and before Muhammad was pronounced prophet. 
The moment that Prophet Muhammad received the first of Qur'anic verse was an enlightening moment in the period of ignorance. After the passing of Muhammad, his close friends and followers started putting down verses of Qur'an onto barks of trees and compiled them into the Qur'an we know now. The compilation of Qur'an verses marked the beginning of Islamic and Arabian literacy practices.

Thousands of years after the revelation of the first word of Qur'an, the fight against illiteracy is still ongoing in the Muslim's world. IINA (2015) reported that around 40\% Muslim population in OIC (Organization of Islamic Cooperation) are still illiterate. The report also identified the factors that caused the high percentage of illiteracy level. Among them are economic disparity among Islamic countries, the diverse historical - cultural background of these countries, and the languages and the literacy cultures that some of those countries inhabit.

Faith or the acts of practicing faith are inseparable part of Muslims' literacy practices around the world with Qur'an as the main texts to read, recited, taught, and studied. The practices of teaching and learning of Qur'an in the context of a Somalian Islamic school, for example, mostly emphasizes memorization and transcription of Qur'anic texts without comprehension of their literal meaning (Moore, 2011). This schooling tradition is widely believed by nonparticipants to have a stultifying effect on children's cognitive and linguistic development, even though there is no empirical evidence to support such claims (Wagner, 1993). Furthermore, Moore (2011) also reported that in such school, a child was expected to recite part of the Qur'an from memory (essential to the five daily prayers), handle the Qur'an respectfully, and listen to Qur'anic recitation and citation (frequent in this community) with the proper speech, demeanor, and affect. Correct response to and rendering of the sounds of the Qur'an constituted the essential first layer of understanding of the sacred text.

For non-Arabic Muslims like the Somalians, learning Arabic is a Sunnah, i.e. a practice which is highly approved or modelled by Prophet Muhammad, because it is the language with which the holy Qur'an is written. For the Arabic Muslims, apart from the motivation of learning the language of the holy Qur'an, learning the language is also part of maintaining their heritage / culture. These two groups, each with their own histories and cultural background, are met in places like the United States, or in particular, in American mosques. Al-Ikhlas is one of those mosques in the Mid-West of United States where a group of 14 multicultural background students of $6-15$ years old are learning to maintain / pass on the heredity and the act of piety. The use of artifacts (textbooks, worksheets and Homework book), understandings of knowledge transfer process, and concept of transfer knowledge as acts of piety and obedience are three factors that outline the atmosphere and the teaching and learning process in Al- Ikhlas weekend school.

This ethnographic study was guided by the following questions: "How does faith / ideology influence the teaching and learning of Arabic? How is language used as a medium for social interaction and mediating meaning and the culture of the community?" As a Muslim coming from Indonesia, Muslim's most populated country in the world, I consider the opportunity of conducting a study within a Muslim's community in United Sates as an effort to "make the familiar strange" (Heath and Street, 2008; Mehan, 1982 ), in which I know enough about the mosque and the community and curious enough to reveal what lies between the lines.

\section{Faith-Based Education and Practices: Orality and Memorization}

The studies in literacy practices primarily involve the use of texts during reading and writing events (Bumanglag \& Ocampo, 2011; Parlindungan, 2017). According to Mckennad \& Richards (2003, cited in Bumanglo and Ocampo, 2011) texts are ideological, which means that they constitute thinking, behavior and ideas that people have about the world and its peoples and are embedded in a context of a situation and come from sets of beliefs and assumptions about the world. 
In a study about the practices and pedagogy of Hindu's traditions on teaching scared text, Fuller (2001) identified, at least, some classical approach that he referred as "the classical mode of religionbased education". These practices primarily involve orality and memorization, in which certain situations are expected / made to happen. First, students are to display total obedience to their teacher. Second, accurate memorization of texts and pronunciation is the overriding priority. Third, to check the memorization of students, there needs to be regular (annual) examinations. Fourth, students are to adhere to strict disciplines. Fifth, oral recitation of texts. Sixth, learning orally with extensive rote memorization (learn by rote), and seventh, the dominant role of teachers, where teacher is considered the source of knowledge.

Noll (2003) investigated the different effects of memorizing bible verses techniques in kindergarten class through songs and through regular memorization. He found that memorizing through songs showed some significant impacts on students' memorization of bible verses. The three studies show that orality and memorization, indeed, are very important parts of faith - based classroom pedagogy and literacy practices. In the classrooms where texts are sacred, memorization and orality are seen as the acts of God appeasing and make the practices as sacred as the texts.

The studies of the Muslims' education and literacy activities often discussed its binary positions with its counterpart, the west. For example, comparing it to the western education, Progler (2001) found that the Muslim's education is introverted, in the way that it "introduces Islam and its relevance in private life but without engaging the normative assumptions and associations of western modernity." Similar findings also found in Parlindungan's (2019) study on the literacy teaching and learning in an Islamic school situated in the U.S. From a different perspective, Hardaker and Sabki (2015) found that Al-Ghazali's mystical-theoretical approach toward learning is implemented to acculturate learning in many Islamic schools. The approach considers madrasah / Islamic schools as a "spiritual rather than social construct" and is optimized by the embodiment of learning. By stressing on the dyadic "heartfelt" relationship between teachers and students, the pedagogy in the Islamic contexts also involves orality and memorization towards sacred texts.

\section{Sociocultural Theory's Perspective on Literacy}

Barton, et al. (2000) consider literacy as a social practice. They elaborate reading and writing (of texts) as a social process that connects people to one another, in which they are embedded in the ideologies and social identities and then are shared and shaped continuously. They argue that: "literacy practices are the general cultural ways of utilising written language which people draw upon in their lives". Barton, et al also believe that literacy practices are culturally constructed and rooted in the dynamic and the changing of the lives and the societies. It means that to understand literacy practices of a community one needs to visit and be with the community to understand the ideology, culture and traditions on which current practices are based.

Orellana (2015) loves the idea that sociocultural approach could foster the full development of human potential, where growth is shaped by social and cultural processes, including their material conditions. (p. 42) Hence, in her study at B-club, she encouraged undergraduate students working with her to reframe their thinking from deficits to assets (focusing on potentiality rather than problems). Unlike the development theory that sees people and their environment separately, Rogoff (2003) perceives individuals as inseparable part of the environment. She stresses the importance of paying attention on aspects of individuals, social influences, and cultural influences, interpersonal, historical and institutional, if one wants to understand a literacy practice. Rogoff believes that people develop as they actively contribute to the sociocultural activities by using the inherited practices and creating new ones. 
Literacy, according to Barton et al (2000), is a set of social practices that are "observable in events which are mediated by written texts". Domains (families and work, for example), discourse communities (informal events) and organizations (like schools and educational institutions) regulate (agents) and are regulated (communities) by literacy practices.

By comparing her theory with the development theory and Vygotsky's socio-cultural historical theory, Rogoff stresses that human learn or develop themselves from their interactions with the sociocultural literacy practices. The development (learning) takes place simultaneously as they adopt the old practices and invent the new ones. To study the literacy practices and human's development process, Rogoff suggests that researchers see the phenomena from multiple perspectives and correlated interactions between individuals, socio-cultural influences, interpersonal relations, and historical background.

\section{Method}

According to Mehan (1982), the ethnographic approach is the most suitable method to portray the (socio) cultural elements of classroom events because it is not mere description of behavior associated with a cultural group. It is, instead, an abstract theory that interprets cultural behavior of certain settings; home and community practices, histories, and activities of students and communities in the process of school learning and access. Thus, literacy practice is often the area of the classroom events often studied.

The observation took place in Al-Ikhlas Mosque, which is located in a city in Midwestern part of United States. The mosque held regular weekly-based Islamic studies and Arabic literacy classes for children aged $6-15$ years old. The students were of different ethnical background and mostly born in the United States. Most of them spoke English fluently since they used English at homes and schools. The class I observed was a male only class, comprising 14 students and was taught by an adult female teacher.

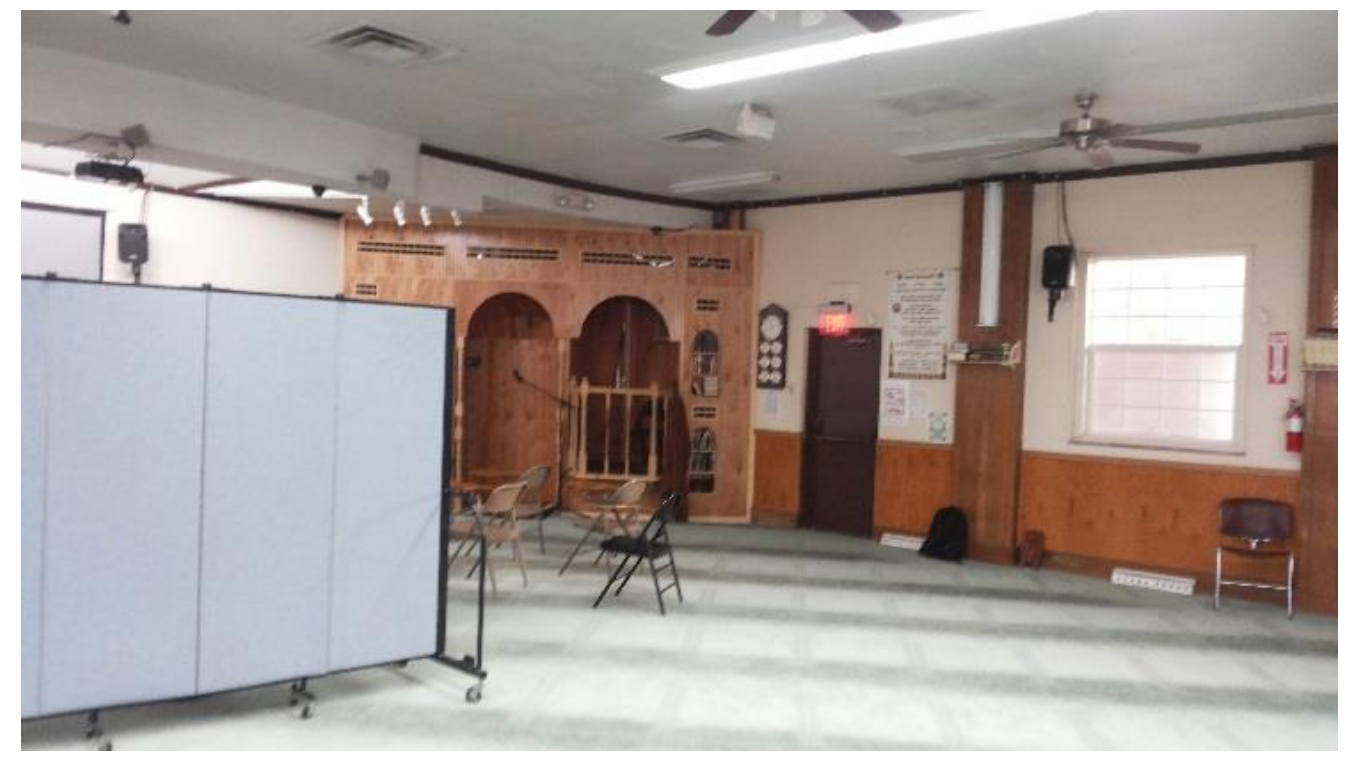

Figure 1. The space for learning

The ethnography methods allowed me to have an intimate look at the participants' literacy practices in the context of their culture. I used multiple methods to gather data such as interview, classroom observation, collection of texts, and artifacts related to the literacy practices at the school thus allowing me as researcher to describe, analyze and interpret the teaching and learning Arabic in the multicultural context. Participants for this ethnographic study were 14 male students of multicultural 
background: white and black Americans, Arabic descendants, south Asians, and Somalians - migrant. Table 1 presents a summary of the sample demographics. Names are all pseudonyms.

The data gathered from interview with the principal, the interactions with some parents and students, and some people working at the mosque are not included to the analysis of this part of the report. Yet, under further development and more detailed representation, their voices could still be analyzed and represented in writing of different perspectives.

Table 1. The demography of Students' Origins

$\begin{array}{llll}\text { No } & \text { Names } & \begin{array}{l}\text { Country of Origins / } \\ \text { ethnicity }\end{array} & \text { First Language } \\ \mathbf{1} & \begin{array}{l}\text { Abu, Mohammed, } \\ \text { Somalia }\end{array} & \text { English } \\ \mathbf{2} & \begin{array}{l}\text { Rashid } \\ \text { Hanif, Habib }\end{array} & \text { Bengali } & \text { English } \\ \mathbf{3} & \text { Jason, Rob } & \text { African American } & \text { English } \\ \mathbf{4} & \text { Adam } & \text { White American } & \text { English } \\ \mathbf{5} & \text { Takur, Syahrur } & \text { Indian } & \text { English } \\ & \text { Khan, Aamir Khan } & & \\ \mathbf{6} & \text { Mohammed Naya } & \text { Arabic } & \text { English } \\ \mathbf{7} & \text { Ali } & \text { Algeria } & \text { English } \\ \mathbf{8} & \text { Ahmad Thoha } & \text { Egypt / Egyptian } & \text { English }\end{array}$

To study the literacy practices and human's development process, Rogoff (2009) suggests that researchers see the phenomena from multiple perspectives and correlated interactions between individuals, socio-cultural influences, interpersonal relations, and historical background. Data collection for this study relied upon participant observation, interviews, collection of texts and artifacts. It was done for three (3) months, from January to April 2016. The researcher visited the mosque on Saturdays and joined the teaching and learning process, from $9 \mathrm{am}-12 \mathrm{pm}$. To analyze the practices of teaching and learning of Arabic in the class of young male Muslims, I identified patterns in the data taken from observations and interviews through coding and theme analysis using the sociocultural theoretical and conceptual framework.

\section{Findings and Discussion}

The data was summarized from six field notes of classroom observation, interactions, with the students, and interviews with 1 female teacher, and the male principal. The six-time observations presented classroom regularities and teaching and learning methodologies that I identify as patterns of teaching and learning in the class. Having coded the field notes and the transcripts, I found that Arabic, letters, memorizations, and students' behaviors are four elements that most frequently appeared in the interactions. Four of are coded into 4 categories: literacy, component of literacy, methodology, and students as objects, which dominates the discourse and the actions of the context. Arabic, referred to as the skill and the target for literacy, despite the other lessons that need to be covered i.e., Qur'an and Islamic studies, were pretty dominant. It appeared in the teaching - learning process, the conversation between the teachers and the principal, and the talk they had with me over the teaching and learning of Arabic literacy.

Letters mostly appeared in the interactions happening between the teacher and the students. The focus of the teaching of Arabic literacy, is at the basic level where students are taught to identify, copy, reproduce, and join / combine Arabic letters. The letters also represent the students' struggles and attitudes in learning Arabic and the teacher's methodology of teaching. The students have been treated as the objects of learning who, most of the time, work individually in receiving information, memorizing, reciting verses of Qur'an, reading out loud, copying and joining letters, and coming 
forward to write on the board. As methodology, memorization seems to be the methodology that the teacher used most of the time. From the interview and the observation, the teacher expects that students memorize the verses from Qur'an on each session.

The second groups of data that frequently appeared in the interactions are the activities of the teachers and the students, the teaching methodologies, the behavior control methodologies, and the focus of the teaching. The medium frequency of students being proactive in their learning, diminish my assumption on students being only the object of learning.

However, the students' participation, agency in learning, were shown mostly on students voluntarily coming to the front of the class to join letters that the teacher assigned. Teacher's activities included regularly checking students' memorization of the verses, recitation, pronunciation and homework book. The teacher acted as the quality control in which all the work must have been done properly, the words were pronounced properly, and that the students behaved in acceptable standards.

\section{Classroom Interactions}

Despite the objective of learning Arabic, the language used to mediate learning has been English. Arabic was only spoken by adults, teachers and parents in the space. Some students said that their parents occasionally talked with them in Arabic, but English was mainly used as the first language at home, at school and even at the $\mathrm{Al}$ - Ikhlas community where they learn Arabic, Qur'an, and Islamic studies. The teacher strived to use Arabic in short phrases and separate words. One word that the teacher often used in the class had been the word Ta'al, an Arabic word that means 'come here'.

The following excerpts of interactions took place between the teacher - and the students. I choose these two excerpts for two reasons: first, (with variations) they happen regularly and second, they both represent the practiced (and believed) culture and meaning making activities during the class.

\section{Excerpt 1}

T: Put your feet down. Both of you!

Mohammed \& Abu Bakar: (put their feet down)

$\mathrm{T}$ : ... when you write the word correctly, not missing any letter, not because you have to

do it but because it is good. I want you ... I found some students; they have done wonderful job. I can tell, they have worked very hard. Like Adam. He has worked very hard, to learn.

\section{Excerpt 2}

Teacher: (firmly) ...there is nothing to be shamed from memorizing your holy book. It is only three ayyah (verses). I asked you to memorize it last week. Now, do you memorize it Mohammed Naya?

Mohammed Naya: mmmh...no.

Teacher: (disappointed tone) Thanks. I will speak to your parents about this and I hope

(after the teacher talks to the parents) you will show me that you memorize it.

The interaction from excerpt 1 showed that the interaction was dominated by the teacher and power was rarely distributed to students. The atmosphere and the practices at school were akin to practices of many formal schools I know where "improper" behaviors are fixed and certain behaviors and achievement to the outcome are rewarded. In sequence, here is the regular teaching and learning process at Al-Ikhlas Mosque. 

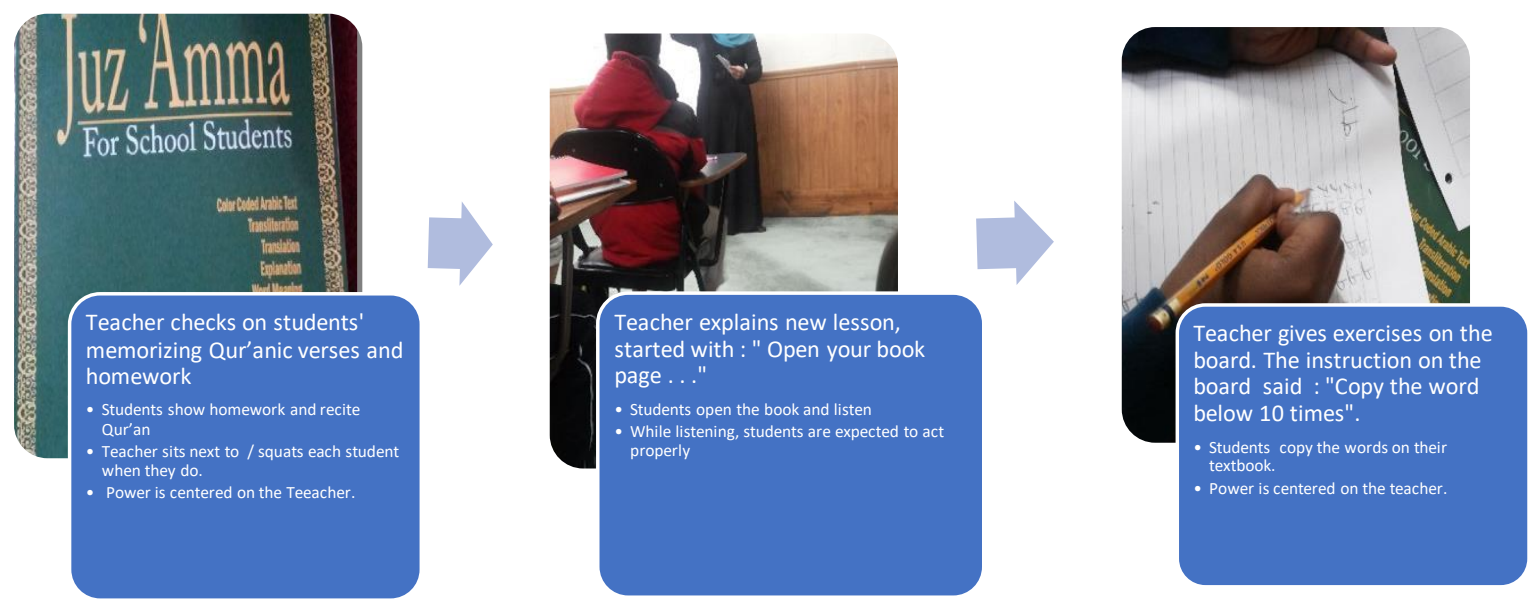

Figure 2. Teaching \& Learning process at Al-Ikhlas Community

The interaction in excerpt 2 shows the expectations of the class / teacher on students. The teacher stated the expectations explicitly and regularly during the class while students were to perform memorization of a number of verses from Qur'an each week. Failure to perform memorization would result in reprimands or a "talk to the parents." Many students took this for granted, causing frustration on the teacher side. The teacher relied on the stimulus-response interaction in order to make learning happen in the class. However, if it is seen through the sociocultural lens, the classroom interaction in the class symbolize the ideology, the history, and the culture of literacy learning in some faith-based schools (Moore, 2013; Hardaker \& Sabki,2012; Fuller, 2001; Noll, 2003; Parlindungan, 2019). In an interview, the teacher critiqued the English language learning in Saudi Arabia which was, is grammar and reading - based and that it lacks exposures on speaking practices for students. Observing the way that she handled the class and reflecting on the interview I had with her, it was apparent that the teacher was practicing what was culturally inherited to her.

\section{Knowledge Transfer: Teaching and Learning}

In my experience of attending Arabic literacy class as a young boy, I notice that obedience, respect, discipline and morality are strongly maintained values. The values are often interpreted differently in their implementation in the classes. This was actually in line what was described by Fuller (2001) on the classical method of pedagogy in faith-based classroom. In the case of Al-Ikhlas weekend school, the teacher's understanding of the four values influenced the way that she interacted with her students. The interaction in except 1 showed how she expected students behave and act in her class:

Teacher: Put your feet down. Both of you!

Mohammed \& Abu Bakar: (put their feet down off the chairs)

The use of textbooks in the classroom also influenced the ways that the teacher communicated with her students. The instructions like: "Open your book page $\mathrm{xx}$ " or "have you done your homework on page 
$\mathrm{xx}$ " were repetitively used. The teacher took prominent role in the class and as one who: instructed (access books and recite qur'anic verses), gave rules (encouraged/praised positive attitudes and prohibited negative behaviors), and demanded outcomes (homework done, and verses of Qur'an remembered). The class appeared to lack what Vygotsky believed as "dialog and social interaction" (talks outside the class instructions or order).

In an interview, the teacher said that she liked teaching and that she was trying her best to do well in teaching. She also said that the reasons for her to do it because Arabic was the language of her mother tongue (that she felt obliged to maintain) and that she wanted everyone (all the young Muslims) to know the language to be able to read Qur'an, as it was expected by the religion and their parents. The teacher understood the background and shared similar history and culture with the majority of parents and students.

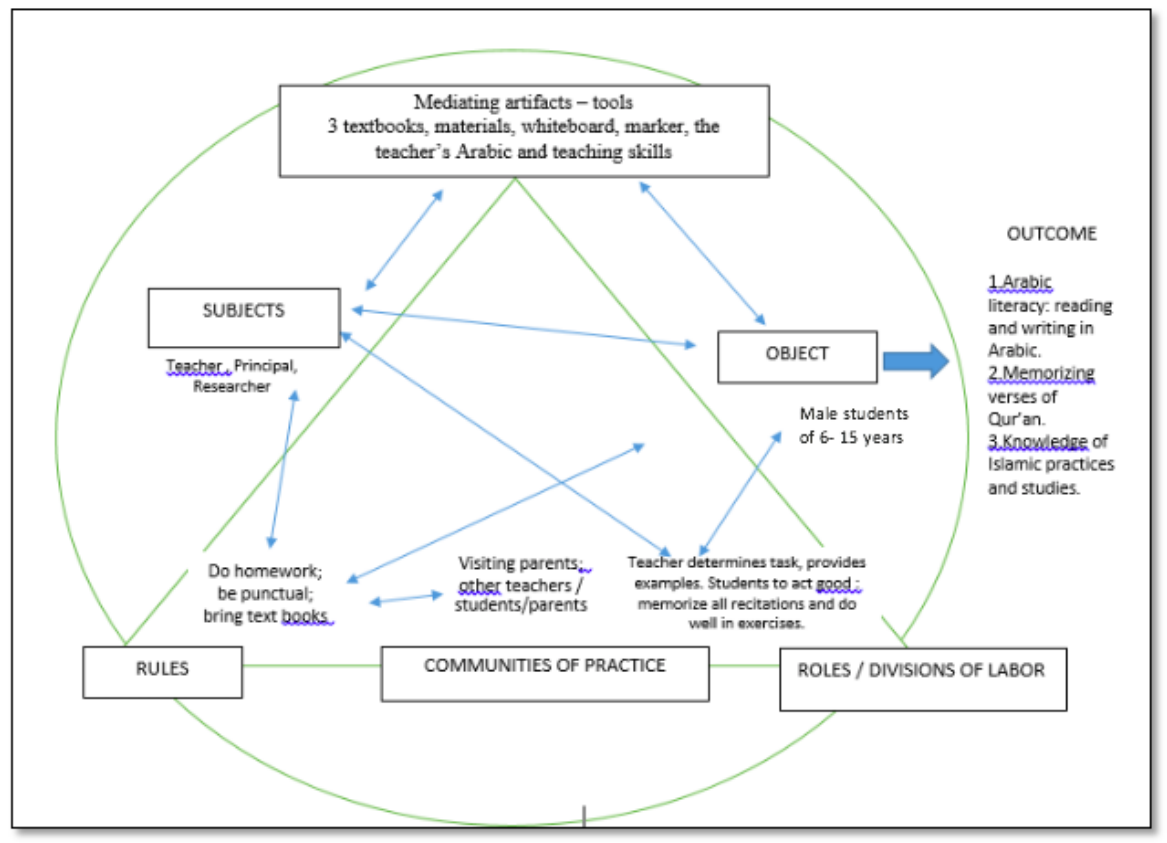

Figure 3. The Activity Diagram

*The green circle represents the ideology of learning Arabic as an act of piety,

a task of maintaining a holy language.

\section{The Mediating Tools}

Semiotic mediation is key to all aspects of knowledge co-construction. For Vygotsky, semiotic mechanisms (including psychological tools) mediate social and individual functioning, and connect the external and the internal, the social and the individual (Wertsch and Stone, 1985). Vygotsky (1981) listed a number of examples of semiotic means: "language; various systems of counting; mnemonic techniques; algebraic symbol systems; works of art; writing; schemes, diagrams, maps and mechanical drawings; all sorts of conventional signs and so on" (p. 137).
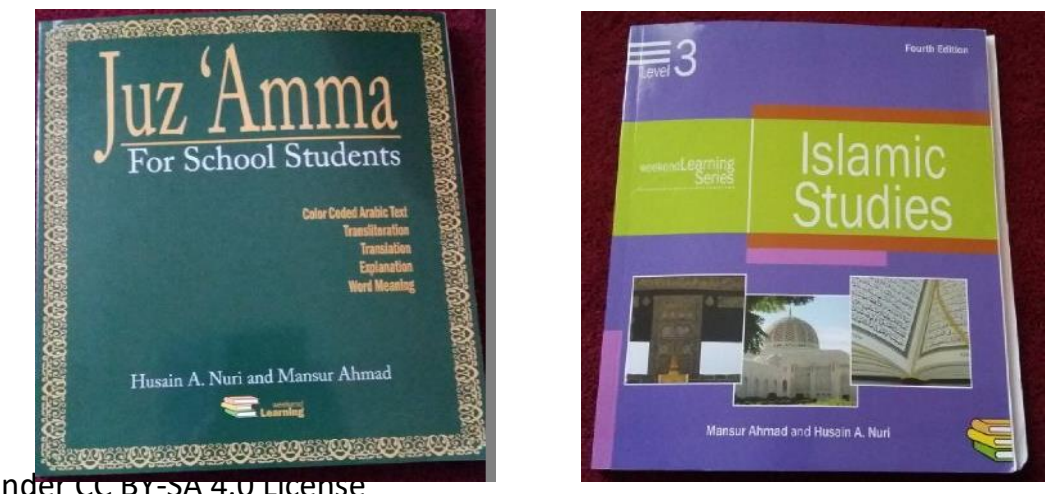


\section{Figure 4. Texts used in Al-Ikhlas mosque}

Textbooks have been very important parts and integral of teaching and learning. In many different contexts and culture, they are used as means to portray and preserve cultures (Parlindungan, et. al., 2018) or supplementary foreign language teaching (Fariduddin \& Parlindungan, 2018; Pransisca \& Rizki, 2020). The literacy practices at the class practically involved three sources of texts: Juzz 'Amma (a chapter in Qur'an), Islamic Studies textbook, and Worksheets. The three mediating tools are used every week to exercise different skills. The juzz amma book is used as source for memorizing and orality practices. Islamic studies is the book for the students to read together for meaning, and worksheets are the medium for students to practice their Arabic writing.

\section{Shared Ideology}

The stakeholders, teachers, parents and students, believed that their involvement at the school as an act of devotion or piety to God. The Al-Ikhlas community also had a shared understanding and value on the importance of sustaining and being good at Arabic literacy. Thus, it became the ideology and the culture of the community. According to Nasir \& Hand (2006):

Ideologies are viewed as having the potential to both limit and enable human action (Giroux,1997). They are material and constituted in meaning and are another means by which social structure is reproduced and is constructed in human minds, actions, and interactions.

The members of the community were interpreted the ideology differently. The teacher, who defined teaching and learning Arabic as part of devotion and a way to preserve her shared heritage, took the teaching job as a serious matter. The engagement with students was meaningful for her as she believed that she had done what was required (in her faith) to teach. In terms of approaches in teaching Arabic literacy, perhaps, both she and I could reflect on what Orellana (2015) said that "human beings learn best through their engagement in meaningful activities, driven by authentic purposes and goals, and supported in their learning through the use of cultural tools and social relationships (p. 42)". Her approaches in teaching were predominantly influenced by her past experience as a learner of Arabic. By continuously referring and reviewing the previous lessons before starting with the new ones, it seems to me that the teacher scaffolded her teaching. That is an important resource to move for inquiry model of reflective teaching. New knowledge, according to Gee (2000), is produced through the process of dialogic mediation and appropriation. Thus, learning may be understood not simply as gaining participation but changing structures of participation through collaboration of situated social practices.

The parents who sent their students to the weekend class were motivated by the same things with the teacher. Unfortunately, as the teacher often complained, the parents often ignored their children's homework and left all the teaching and learning responsibilities onto the teacher's hands alone. The students, as young as they are, seemed to get lost in 'the circle'. Even though the teacher and parents encouraged these young men relentlessly on the importance of learning and sustaining Arabic literacy, I found many of them were still confused with their presence in the space.

In their studies of An Islamic school in United Kingdom, Hardaker and Sabki (2015) revealed a concept of Islamic pedagogy which embodies Al-Ghazali's mystical-theoretical approach toward learning where schools are spiritual rather than social construct. In his approach, Al-Ghazali believes that the heart is a transcendental spiritual that he defines as the essence of being human, which comprehends, learns, and knows (Al-Ghazali, 1853; Gunther, 2007 as cited in Hardaker and Sabki, 2015). The concept of school as "spiritual rather than social construct" may seem contradictory with sociocultural lens to learning, which relies on the dialog or the social interactions among community members.

This article is licensed under CC BY-SA 4.0 License 
Islam embraces a concept of Hablumminalloh waa hablumminannaas, which literally means "human relationship with God and human relationship with other fellow humans". It encompasses the ideas that human's life should not be dominated by the 'worldly' or 'godly' matters only. In other words, human's life should be in balance between serving God and having good social relationship with other human beings.

In the interaction between teacher and students, Al-Ghazali signifies roles of 'the heart' as the essence of human being in teaching and learning (to comprehend, learn, and know). Similarly, Orellana (2015) believes that 'love' should be the essence of every teacher or adult's actions in teaching and learning. She uses 'heart' in the center of her term: Pedagogy of the heart. She says that, "teaching is an act of love, aimed at helping people to become full conscious, develop their full capacities, and fulfill their own needs in communion with the needs and aspirations of others" (p. 49).

The teacher inherited the practices of teaching and learning of Qur'an and Arabic literacy. Her approach was justified by her references of past, successful practices. The students, on the other hand, demonstrated mixtures of perspectives. The teacher's acts of teaching were predominantly motivated by two types of love: love of her God and love of her students. The principal's dedication of his job was motivated with the similar sort of love. So were the parents' motivations of sending their children to the school. The children may not have been motivated with similar feelings, but gradually, as they grow older, through constant dialogs and heartfelt communications, they would learn the same fondness and longing for the mosque, for God, and for their fellow teachers and friends. The same reasons and feelings that they would use to send their children to the mosque.

\section{References}

Barton, D. (2000). Researching literacy practice: Learning from activities with teachers and students. In D. Barton, M. Hamilton, \& R. Ivanic (Eds.), Situated literacies: Reading and writing in context (pp. 167-179). New York: Routledge.

Bumanglag, C.A. \& Ocampo, D. (2011) Literacy Practices and Constructions Among Migrant Muslim Filipino Families. Education Quarterly, 69 (1), 15-32.

Cameron, D. (2001). Working with spoken discourse. London: Sage Publications. pp. 53-67. ISBN 978-0761957737.

Enciso, P. \& Ryan, C. (2011) Sociocultural Theory: Expanding the Aims and Practices of Language Arts Education, in Lapp, D. \& Fisher, D. (Eds.) Handbook of research on teaching the English Language Arts. Routledge.

Fariduddin, M., \& Parlindungan, F. (2018). Comprehending narrative text: the effectiveness of cooperative integrated reading and composition (CIRC). Ethical Lingua: Journal of Language Teaching and Literature, 5(2), 139-148.

Fuller, C.J. (2001). Orality, Literacy and Memorization: Priestly Education in Contemporary South India. Modern Asian Studies, 35, pp 1-31 doi:do1:10.1017/ S0026749X01003717.

Gee, J. P. (2000). The New Literacy Studies: From "socially situated" to the work of the social. In D. Barton, M. Hamilton, \& R. Ivanic, R. (Eds.), Situated literacies: Reading and writing in context (pp. 180-196), New York: Routledge.

Hardakera, G. \& Sabkib, A.A. (2015). Islamic Pedagogy and Embodiment: An Anthropological Study of a British Madrasah. International Journal of Qualitative Studies in Education, 28, (8), 873886, http://dx.doi.org/10.1080/09518398.2014.917738

Heath, S.B. \& Street, B.V. (2008). On Ethnography: Approaches to Language and Literacy Research. New York: Teachers College Press.

Holland, D., Lachicotte Jr. W., Skinner, D., \& Cain, C. (2003). Identity and agency in cultural worlds. MA: Harvard Univ Press.

This article is licensed under CC BY-SA 4.0 License 
Hymes, D. (1964). "Introduction: Toward Ethnographies of Communication". American Anthropologist. 66 (6): 1-34.doi:10.1525/aa.1964.66.suppl_3.02a00010.

IINA Report ( 2015). Nearly 40\% of Muslim world's population unable read or write: IINA Report http://www.iinanews.com/page/public/report.aspx?id=10377\#

Moll, L. (2014). L.S. Vygotsky and Education. NY: Routledge.

Mehan, H. (1982). The Structure of Classroom Events and Their Consequences for Students' Performances. Gilmore, P. \& Galtthorn, A. (1982). Children In and Out of School.

Moore, L. (2011). Research Directions: Moving across Languages, Literacies, and Schooling Traditions. Language Arts, 88, (4), pp. 288-297.

Nasir, N.S. \& Hand, V.M. ( 2006). Exploring Sociocultural Perspectives on Race, Culture, and Learning. Review of Educational Research, 76, (4), pp. 449-475.

Orelana, M.F. (2015). Immigrant Children in Transcultural Spaces : Language, Learning, and Love.

Paris, D. (2012). Culturally Sustaining Pedagogy: A Needed Change in Stance, Terminology, and Practice. Educational researcher, 41: 93. DOI: 10.3102/0013189X12441244

Parlindungan, F. (2017). Exploring literacy practices in a second language. TEFLIN Journal, 28(1), 115-132.

Parlindungan, F. (2019). The literacy teaching and learning in a classroom: A case study in an American Islamic school. Unpublished Dissertation. Available online at https://etd.ohiolink.edu/!etd.send_file?accession=osu $1554578759732856 \&$ disposition=inline

Parlindungan, F., Rifai, I., \& Safriani, A. (2018). The representation of Indonesian cultural diversity in middle school English textbooks. Indonesian Journal of Applied Linguistics, 8(2), 289-302.

Prancisca, S., \& Rizqi, M. A. (2020, January). Developing a Local-Based Book as a Supplementary

EnglishTeaching Material for Undergraduate Students. In UICELL Conference Proceeding (pp. 213227).

Progler, J. (2001). Chapter 26: Norms and Allegiances in Muslim Education. Counterpoints, 94, 565591.

Rogoff, B. ( 2003) The Cultural Nature of Human Development. Oxford University Press.

Urrieta, L. (2007). Figured worlds and education: An introduction to the special issue. The Urban Review, 39(2), 107-116.

Vygotsky, L.S. ( 1978). Mind in society : the development of higher psychological processes. Cole, M., John-Steiner, V., Scribner, S., Souberman, E. (Eds.). Harvard University Press, Massachusetts 